\title{
ĆWICZENIE WYOBRAŹNI SOCJOLOGICZNEJ: POLSKA FUTUROLOGIA NAUKOWA LAT 70. XX WIEKU
}

Lukas Becht

Uniwersytet Ludwika-Maksymiliana w Monachium/Uniwersytet Wiedeński

Piotr Filipkowski

Instytut Filozofii i Socjologii Polskiej Akademii Nauk/Uniwersytet Wiedeński

\section{/// Wstęp: Historyczna socjologia przyszłości w antropocenie}

Podczas „Długiej Nocy Nauki” zorganizowanej w kwietniu 2018 r. na Uniwersytecie Wiedeńskim ani humanistyka, ani nauki społeczne nie zajmowały szczególnie eksponowanego miejsca ${ }^{1}$. Z jednym wyjątkiem. Otóż na jednym z centralnych placów miasta stanęły namioty, w których młodzi humaniści opowiadali o antropocenie: nowej epoce w historii naszej planety, którą charakteryzować mają trwałe, nieodwracalne ludzkie ślady odciśnięte w jej geologicznej strukturze (Crutzen 2002).

Brak zgody co do tego, jak długo antropocen już trwa ani kiedy się skończy. Bez wątpienia chodzi o czas w perspektywie historii Ziemi ultrakrótki, choć w swoich konsekwencjach sięgający daleko w przyszłość. Nie początek tej ery budzi bowiem największe emocje, lecz jej już dzisiaj przewidywany kres, radykalnie przyspieszony destrukcyjna wobec przy-

1 Dziękujemy za konstruktywną krytykę i cenne uwagi Agacie Stasik, Jakubowi Motrence, uczestnikom tematycznego seminarium redakcyjnego oraz anonimowemu recenzentowi. Część badań, których wyniki przedstawia najniższa publikacja, była zrealizowana dzięki wsparciu w ramach strategii „LMUexcellent” na Uniwersytecie w Monachium oraz stypendium w Niemieckim Instytucie Historycznym w Warszawie. Część natomiast w ramach grantu Narodowego Programu Rozwoju Humanistyki „Archiwum Danych Jakościowych przy IFiS PAN” (0027/NPRH2/H11/81/2012). Jeśli nie podano inaczej, wszystkie cytaty z literatury obcojęzycznej w przekładzie autorów artykułu. 
rody aktywnością samego człowieka. Wizje przyszłości budowane w ramach dyskusji o antropocenie koncentrują się na wynajdowaniu sposobów spowolnienia tej (samo)zagłady albo refleksyjnego przygotowania do niej (Scranton 2015).

Jeśli w każdym zjawisku historycznym materializuje się pewien reżim czasowy, który umożliwia, porządkuje jego strukturę temporalną oraz definiuje kategorie rządzące naszą wyobraźnią o czasie i historii, to być może mamy właśnie do czynienia z przedefiniowaniem naszych pojęć temporalnych (Hartog 2015: 8). Rodzą się w każdym razie nowe spojrzenia historyczne przedłużające horyzonty czasowe do początku i końca wszechświata w tak zwanej „Big History” (Christian 2011). Łączeniem dziejów „nieludzkich” i „ludzkich” zajmują się historie przyszłości (Harari 2016). Koncypuje się etycznie świadomą „historię ratowniczą” (Domańska 2014) oraz teoretycznie ambitne ,historyczne studia nad przyszłością” (Hölscher 2017). Zdaje się to potwierdzać diagnozę „kryzysu historycznego myślenia i poczucia bezpożyteczności wiedzy historycznej, z której nie daje się wyprowadzić czy ekstrapolować reguł skutecznego działania w przyszłości (wobec jej zasadniczej nieprzewidywalności)” - wszak z konkluzją, że „klucza do zamkniętych drzwi do przyszłości trzeba jednak szukać w przeszłości” (Nycz 2014: 8).

Problemy przyszłości przyciągały szczególną uwagę polskiej socjologii w latach 60. i 70. w postaci dyskusji o podstawach prognozowania, prognostyki, przewidywania lub „polskich studiów «futurologicznych»” (Siciński 1967: 243). Stawiamy hipotezę, że rekonstrukcja historycznych refleksji nad granicami poznania zasadniczo niepoznawalnej przyszłości z tego kontekstu jest jednym z „kluczy” zwiastujących współczesne redefinicje porządków temporalnych. Działo się to w realiach systemu politycznego PRL z jego założeniami ideologicznymi, ale też w kontekście międzynarodowych początków futurologii, co przybliżamy w rozdziale pierwszym. Rozdział drugi rozróżnia cztery kierunki typowe dla ówczesnych problematyzowań socjologicznej wiedzy o przyszłości.

Celem naszego artykułu nie jest inwentaryzacja treści tych prognoz, a już zupełnie nie jest nim weryfikacja trafności tamtych przewidywań. Chcemy pokazać granice ówczesnej futurologicznej wyobraźni socjologicznej, przy czym nie faktograficzne (przewidywanie „maksimum” tego, co może się przytrafić) ani ideologiczne (co było „do pomyślenia” w ówczesnym reżimie politycznym), lecz teoretyczne i metodologiczne. Skupiamy się na tym, jak futurologiczne „ćwiczenia socjologicznej wyobraźni” (Szacki 1980: 187) (prze)definiowały pojęcie przyszłości. 


\section{/// 1. Zarys genezy futurologii naukowej w Polsce}

Historia kultury daje mnóstwo przykładów „technik prospekcji” służących wyobrażaniu sobie nieznanej przyszłości (Mallard, Lakoff 2011: 340). Sięgają one od wyroczni delfickich, przez przepowiednie mesjanistyczne, utopie, oświeceniowe wizje postępu, do dzisiejszych postapokaliptycznych scenariuszy końca świata, które pojawiły się już w romantyzmie (Minois 1996, Hölscher 1999). Opieranie ich na wiedzy naukowej stało się jednak powszechne dopiero pod koniec XIX w., wraz z wiarą w możliwość planowego kształtowania przyszłości (Seefried 2015: 39). Te „naukowe” wyobrażenia miały i mają skutki polityczne - są przykładem ścisłego związku między wiedzą i władzą (Foucault 1976: 39). Historycznie zazębiają się zatem ze zjawiskami dyskutowanymi pod pojęciem ,inżynierii społecznej” (Etzemüller 2017). Mimo gruntownej świadomości tych związków dopiero od niedawna systematyczniej bada się rolę technik prospekcyjnych w gospodarce kapitalistycznej (Beckert 2016: 217-244), a nauki historyczne wciąż wiedzą relatywnie mało o tym, jaką funkcję spełniły prognozy w socjalizmie (Sommer 2016a, 2017, Catanus 2015, Rindzevičiūtè 2016, Rocca 1981, Seefried 2017).

To samo można powiedzieć o historii futurologii naukowej w Polsce z lat 60. i 70. XX w., przy czym jej specyficzna geneza i ewolucja nie daja się zredukować do jednego z aspektów polskiej wersji (realnego) socjalizmu czy historii intelektualnej PRL ${ }^{2}$. Chcemy wnieść wkład w poszerzenie wiedzy na ten temat.

„Futurologia” - pojęcie rzekomo „odkryte” w 1943 roku przez Karla Ossipa Flechtheima, ukraińskiego uciekiniera do Stanów Zjednoczonych - powstała w specyficznych warunkach historycznych po II wojnie światowej, czyli w obliczu totalnej, dosłownie, inżynierii społecznej. Odżegnując się od niej, a jednocześnie utrzymując ideę ogólnej planowości, Flechtheim (1970: 13) wiazzał z pojęciem futurologii apel o skierowanie „krytycznej i systematycznej uwagi ku przyszłości”, jej prognozowaniu, praktycznemu kształtowaniu i filozoficznej refleksji nad nia. Jednak w zimnowojennym podziale świata wokół tych kategorii rozpętała się ideologiczna konfrontacja z socjalistycznym reżimem centralnego planowania ${ }^{3}$.

\footnotetext{
${ }^{2}$ Opowiadanie historii studiów nad przyszłością w Polsce jest do tej pory w dużej mierze sprawą uczestników (Karpiński 2001, Komitet Prognoz „Polska w XXI Wieku” przy Prezydium PAN 1999). Wyjątkami są nieliczne podejścia problemowe (Sułek 2011b, Kiecko 2018), personalne (Filipkowski 2017, Kurczewski 2009) lub instytucjonalne (Tarkowska 1999, Becht 2017).

${ }^{3}$ Obszerny opis powstania futurologii zachodniej zob. Seefried (2015: 49-69), Andersson (2018, 2012).
} 
Nigdy nie udało się futurologii ukonstytuować dyscypliny akademickiej. Spory budziła sama nazwa, choć pod tym właśnie pojęciem od połowy lat 50. do połowy lat 70. różne prace, inicjatywy, kontrowersje i postaci się ze sobą komunikowały i zyskiwały rozgłos w mediach, wśród intelektualistów oraz elit politycznych i ekonomicznych, także w Polsce. Charakterystyczny opis zjawiska znalazł jeden z polskich uczestników konferencji Światowej Federacji Studiów nad Przyszłością (założonej cztery lata wcześniej w Bukareszcie) w podwarszawskiej Jabłonnie w 1977 r., mówiąc o ponadnarodowym future studies movement (Święcicki 1978). Z archiwów PAN i Wydziału Nauki KC PZPR trudno dowiedzieć się więcej o okolicznościach tej konferencji. Jednak dowodzi ona, że ukonstytuowane mniej więcej dekadę wcześniej polskie studia nad przyszłością wpisywały się w ponadnarodowe dyskusje oraz ich recepcję. Poza (1) transferami wiedzy w ramach rozwoju futurologii po 1956 roku za kluczowe dla jej genezy w PRL uważamy (2) miejsce w socjalistycznym polu naukowym oraz (3) stosunek do oficjalnej ideologii politycznej.

(1) Jest w tym pewna ironia, że w PRL po 1956 roku nawet intelektualiści przekonani o wyższości socjalizmu i marksizmu nad perspektywami „burżuazyjnymi”, dobrze zorientowani w radzieckich dyskusjach naukowych, inspirowali się zachodnimi studiami prognostycznymi powstałymi w konkurencji z komunistycznym pojęciem planowości ${ }^{4}$. Pod rządami Stalina $\mathrm{w}$ ZSRR dyskusje o kompleksowym prognozowaniu $\mathrm{z}$ początku lat 20. faktycznie ucichły, a symboliczną władzę nad czasem sprawowała arbitralna wola kierownictwa politycznego zoperacjonalizowana w cyklicznych planach. Dyktowano w ten sposób bezalternatywną wizję przyszłości (Plaggenborg 2006: 97), a rygorystyczna cenzura usiłowała zatrzymać rozpowszechnienie „burżuazyjnych” teorii i metod.

Tymczasem w amerykańskim Think Tanku RAND Corporation od końca lat 40. eksperymentowano z teoria gier i racjonalnego wyboru, analizami systemów i modelami cybernetycznymi w prognozowaniu następstw decyzji wojennych, technologicznych i zbrojeniowych. Tu doszło do kluczowej reorientacji: podczas gdy pierwsze komputery budziły nadzieje na dokładne przewidywanie zdarzeń i zbiegów okoliczności, szybko okazało się, że ich moc tkwi raczej w ukazywaniu wachlarza różnych scenariuszy. Zaczęto zatem operacjonalizować koncepcję wielości możliwych przyszłości przy pomocy nowych narzędzi prognostycznych. Powstały symulacje modelowe na podstawie wtórnych kalkulacji probabilistycznych, pisanie

\footnotetext{
${ }^{4}$ Wytknął to socjologom ekonomista Czesław Bobrowski w ramach dyskusji na pierwszym polskim kongresie „futurologicznym” w Tardzie (Rażniewski et al. 1967: 111).
} 
scenariuszy i „delfickie” panele eksperckie (Williams 2016: 475 f., Seefried 2015: 60-69).

W rozpowszechnianiu takich koncepcji w intelektualnym obiegu transatlantyckim istotną rolę odegrały w latach 50. amerykański Congress for Cultural Freedom oraz Fundacja Forda. W obu organizacjach działał socjolog Daniel Bell, który rozwinął własną koncepcję przewidywania i szukał współpracy z francuskimi ekspertami z Commisariat du Plan, powstała przy nim prognostyczną „Groupe 1985” oraz z projektem „Futuribles” francuskiego politologa Bertranda de Jouvenela (Seefried 2015: 69-74, 98-100, 106-109). Wspólnym mianownikiem tych inicjatyw była właśnie koncepcja wielości przyszłości oraz roszczenie globalnego zasięgu formułowanych diagnoz i prognoz (Andersson 2012). Punktem wyjścia była diagnoza „krytycznej kumulacji” oraz przyśpieszenia przemian społeczeństw uprzemysłowionych, szczególnie w obszarze technologii, przemysłu, nauki i kultury ${ }^{5}$. Legitymizując studia prognostyczne, pisano o rozwoju „trzeciego sektora" (Fourastié 1954), znikaniu różnic ideologiczno-ustrojowych w „nadchodzacym społeczeństwie postindustrialnym” (Bell 1970), globalnych tendencjach demograficznych (Baade 1962) czy, nieco później, w 1972 roku, o granicach wzrostu (Meadows et al. 1973).

Recepcja tych debat w PRL była niejednoznaczna. Przede wszystkim zostały rozpoznane jako dyskurs ponadnarodowy o rosnącym, przyszłościowym (nomen omen) znaczeniu, w którym warto brać udział. Sprzyjała temu od 1956 do mniej więcej 1961 roku możliwość wędrówki młodych naukowców (i idei) do i z Francji, Anglii, RFN i przede wszystkim „do Ameryki!” (Sułek 2011a: 101-107). Podczas trzytygodniowego seminarium o ekonomicznych, technologicznych i kulturowych aspektach postępu, zorganizowanego przez UNESCO w październiku 1956 r. w Paryżu, młodzi socjologowie i ekonomiści, wśród nich Stefan Nowak, Leszek Kołakowski i Antoni Rajkiewicz, najpewniej poznali z bliska ówczesne dyskusje o rodzącej się futurologii (Meynaud 1957) ${ }^{6}$. Mimo przerwania współpracy z Fundacją Forda w ramach walki z „rewizjonizmem” nauk społecznych, zintensyfikowanej przez Władysława Gomułkę wykładem podczas XIII plenum KC PZPR w lipcu 1963 r., jednostki odpowiedzialne za planowanie badań naukowych przełożyły „dla użytku służbowego” zachodnie

\footnotetext{
5 Trudno przeoczyć, że te diagnozy określające podstawową futurologiczną wyobraźnię z lat 50. i 60 . XX w. uchwyciły przeobrażenia, o których dziś mówi się jako o początku antropocenu, nazywając go „wielkim przyspieszeniem” (Steffen et al. 2015).

${ }^{6}$ Z Antonim Rajkiewiczem jeden z autorów tego tekstu prowadził 2 lutego 2017 r. w Warszawie rozmowę na temat futurologii, podczas której rozmówca zwracał uwagę na znaczenie tego seminarium dla takiej recepcji (nagranie w zasobach autora, L.B.).
} 
publikacje cybernetyków i futurologów, którzy nie kryli swojego antykomunizmu (Gordon, Helmer 1965, Bell 1966, de Jouvenel 1966). Drugim i najważniejszym ośrodkiem dla wykrystalizowania własnej koncepcji badawczej w powiązaniu z tą międzynarodową debatą okazała się jednak Pracownia (później: Komitet) Badań nad Kulturą Współczesną, założona w 1960 r. przez odchodzącego ze stanowiska Ministra Nauki Stefana Żółkiewskiego.

Punktem wyjścia dla tej pracowni była, wówczas jeszcze kontrowersyjna, teza o występujących w PRL zjawiskach kultury masowej. Żółkiewski stwierdził, że teoria marksistowska była wobec tych procesów kompletnie bezradna (Żółkiewski 1963: 215-217), choć miała wciąż oferować fundament dla integracji różnych teorii i podejść dyscyplinarnych (Żółkiewski 1960, Siciński 1996). Andrzej Siciński - obok innych młodych socjologów kultury - znalazł etat u Żółkiewskiego po odejściu z Ośrodka Badania Opinii Publicznej. Tam dalej prowadził swoje badania opinii, wchodząc w międzynarodowy projekt badawczy o rozbrojeniu i obrazach przyszłości świata prowadzony przez Peace Research Institute Oslo, a kierowany przez Johana Galtunga, który aktywnie zapraszał socjologów z krajów socjalistycznych do coraz głośniejszych międzynarodowych dyskusji o futurologii.

(2) Na Kongresie Kultury Polskiej w 1966 r. w Warszawie Andrzej Siciński i Stefan Żółkiewski po raz pierwszy publicznie występowali z pomysłem na prognozowanie kwestii społecznych i kulturowych. W Komisji Planowania przy Radzie Ministrów ich propozycja znalazła wsparcie, choć - jak stwierdzili jej autorzy na przygotowanej zaraz potem konferencji tylko „półoficjalnie” (Czerwiński et al. 1967: 49). W wyniku dyskusji o reformach systemu planowania po 1956 r. Komisja Planowania i PAN jako instytucje odpowiedzialne za planowanie nauki zajmowały się tzw. planowaniem perspektywicznym z horyzontem na 20 lat (Secomski 1962). Od początku lat 60 . było to obowiązkiem wszystkich krajów RWPG zgodnym z wizja szybszej realizacji komunizmu przedstawiona przez Chruszczowa na XXII Zjeździe KPZR w 1961 roku. Obietnica „dogonienia i przegonienia" (Chruszczow 1961) kapitalistycznego Zachodu w horyzoncie 1980 roku dzięki sile naukowej i technologicznej zakładała także większy nacisk na konsumpcyjne podnoszenie poziomu życia. Namacalny sukces radzieckiej misji kosmicznej i pojawiające się możliwości zastosowania komputerów w planowaniu wzmacniały te nadzieje (Sabrow 2009: 125). Jednocześnie przesuwały myślenie o przyszłości w kierunku społecznej „nadbudowy”, co było wyzwaniem dla planistów, ale czyniło też z socjologów ważniejsze źródło wiedzy dla polityków. 
W latach 60. w PRL ścierały się jednak narracje polityczne. Z jednej strony pojawiały się deklaracje przejścia przez etap uprzemysłowienia w fazę, w której technologia, oświata, czynniki kulturowe i socjalne miałyby odgrywać decydującą rolę w osiaganiu sukcesu gospodarczego. Z drugiej zaś - restrykcyjna polityka kulturalna i rosnące uwikłanie dyskursu politycznego w spory historyczne (szczególnie wokół konfliktu o jubileusz roku 966) nakładały się na rosnące aspiracje materialne, kulturowe i polityczne przeważnie w młodszych segmentach społeczeństwa (Paczkowski 2005: 215-219 i 252-255). W takim klimacie w maju 1967 r. odbyła się w Tardzie koło Ostródy trzydniowa konferencja pod tytułem „Przewidywanie przyszłości a model kultury” zorganizowana przez Żółkiewskiego i jego Pracownię. Marcin Czerwiński, jeden ze współorganizatorów, wyjaśnił już po konferencji jej genezę, twierdząc, że w obliczu ówczesnej sytuacji politycznej „re-orientacja ku przyszłości wydawała nam się konieczna”7. Dyskusja o futurologii toczyła się jednak wpierw w dość zamkniętym obiegu i choć zintegrowała różne środowiska intelektualne, a nawet światopoglądowe, to nie odniosła większych efektów politycznych. Jednym z powodów były wydarzenia marcowe w 1968 r. i represjonowanie naukowców pochodzenia żydowskiego.

Pomysł na prognozowanie promowany na konferencji w Tardzie opierał się na propozycjach metodologicznych Jouvenela oraz semiotycznej teorii kultury, tak jednak zinterpretowanych, by atomizująca, konsumpcyjna i pasywna kultura masowa bogatszych krajów zachodnich (jak ją charakteryzowano) nie stała się wzorem dla społeczeństwa polskiego. Wierzono w możliwość rozwijania w Polsce socjalizmu opartego na partycypacyjnym etosie demokratycznym i kulturze „faustycznej czy prometejskiej” (Żółkiewski 1967: 136), nastawionej na cele ponadindywidualne. Różnie można oceniać realizm tamtych oczekiwań, aczkolwiek z perspektywy historycznej warto odnotować, że zasygnalizowały one moment historyczny, w którym z punktu widzenia intelektualistów esencjonalna wydawała się świadomość otwierających się różnych dróg przyszłości.

Alternatywy były jednak mocno ograniczone. Nie zakładano wyjścia poza istniejący ustrój polityczny. Jak dał do zrozumienia Andrzej Siciński (1969: 130), granice alternatywności określała nadal „marksowska makroprognoza". Mimo takiego spętania ówczesnej wyobraźni socjologicznej dyskusje futurologiczne praktycznie od końca lat 60. stały się medium ko-

\footnotetext{
Archiwum Polskiej Akademii Nauk (APAN), Dokumenty Wydziału II Nauk Społecznych (DWNS), II-77 367/139 533, bez paginacji, Stenogram z posiedzenia plenarnego Komitetu Badań nad Kulturą Współczesną PAN odbytego w dniu 6 listopada 1967 r.
} 
munikacji dla propozycji reform: w studiach nad szczególnymi patologiami społecznymi (Falewicz [1970]), w "prognozach ostrzegawczych"8 czy w kontrowersyjnych ,scenariuszach hipotetycznych” (Gotowski et al. 1982) wyjścia z sytuacji kryzysowej wczesnych lat 80 .

(3) Powstanie zinstytucjonalizowanych studiów nad przyszłością w Polsce ostatecznie daje niejednoznaczną odpowiedź na pytanie o rolę prognoz w PRL. Można ją rozumieć jako przejaw szerszej zmiany lub nawet kryzysu w dyskursie ideologiczno-politycznym. W glosie po konferencji w 1967 r. na łamach „Polityki” Jan Strzelecki przypisał systematycznym prognozom socjologów rolę producenta pociągających „symboli średniego zasięgu” po wyczerpaniu sił „powojennej odbudowy”, „sześciolatki” czy „polskiej drogi do socjalizmu” (Strzelecki 1967). Możliwe, że Strzelecki miał przed oczami przykład kolektywu Radovana Richty z Czechosłowackiej Akademii Nauk, który na zlecenie polityków opracował analizę konsekwencji „rewolucji naukowo-technologicznej” łączącą marksizm z filozofią humanistyczną i stającą się jednym z kluczowych dokumentów legitymujących tamtejsze reformy pierwszej połowy 1968 roku (Schulze Wessel 2018: 67-90, Sommer 2016b). Choć uczestnicy wspomnianej konferencji w Tardzie podkreślają nieufność władz wobec podobnej inicjatywy w Polsce, dokumenty archiwalne z Wydziału Nauki KC PZPR, Komisji Planowania i PAN niewiele mówią o faktycznym stosunku partii do futurologii. Na pewno można ją było rozumieć jako próbę uaktualnienia marksistowskiej teorii postępu, ale jednocześnie kryła w sobie potencjał wyjścia poza nią. Wiadomo, że konieczne było zaangażowanie wysokich urzędników Komisji Planowania oraz PAN, żeby wiosną 1969 r. przy prezydium PAN powstał Komitet Badań i Prognoz „Polska 2000”, a w następnym roku kompleksowy system prognozowania dla potrzeb Komisji Planowania (Nowacki 1985: 166-169). W oficjalnych uzasadnieniach mało było już mowy o humanistycznych wizjach socjalizmu, więcej o efektywności, naukowości i konieczności budowania wizji „rozwiniętego społeczeństwa socjalistycznego" w bliskiej współpracy polityków z ekspertami naukowymi (Secomski 1970). Pierwsze lata urzędowania Edwarda Gierka przynosiły właśnie ten rozwój instytucjonalny. W planistach prognozy ukazujące warianty rozwoju budziły nadzieję na "optymalne decyzje” (Secomski 1971: 71). Jak podkreśla Pavel Kolář w swojej analizie „poststalinowskiego" dyskursu ideologicznego partii komunistycznych, te ostatnie po 1956 r. coraz jaśniej budowały swoje narracje siegające poza

\footnotetext{
8 Komitet Badań i Prognoz „Polska 2000”. 1981. Prognoza ostrzegawcza „Lata najbližsze”. Opracowania szcregótowe $i$ aneks metodologičny, maszynopis powielany [w zasobach Biblioteki Narodowej (BN)].
} 
horyzont teraźniejszości na „naukowości” i ciagłym doskonaleniu „realnego socjalizmu" zamiast na rewolucyjnej sile pierwszego sekretarza (Kolář 2016: 288).

Mimo wieloznaczności i historycznego rozwoju socjalistyczne prognozowanie nie wyszło poza ramy tego, co Stanisław Ossowski określił mianem „ładu monocentrycznego” (Ossowski 1967). Wprawdzie wskazywał on na to, że kwestie stosunku do przyszłości i właściwe dla niej techniki prospekcji zyskują na znaczeniu, ale jednocześnie podkreślał, że przewidywania oparte na teoriach i metodach socjologicznych maja sens tylko w społeczeństwach pluralistycznych (,policentrycznych”), gdzie jednostki kierują się w postępowaniu własnymi decyzjami i swobodnie koordynuja swoje działania. W społecznościach tradycyjnych lub „monocentrycznych” przewidywanie socjologiczne zostaje zredukowane do etnografii lub „ustępuje miejsca cybernetyce, $[. .$.$] a strategia [. .$.$] ustępuje miejsca inżynierii”$ (Ossowski 1967: 95). Na tym polu problemowym operowała polska futurologia naukowa lat 70 .

\section{/// 2. Cztery problematyzacje granic socjologicznej wyobraźni dotyczące przyszłości}

Zarysowawszy historyczne uwarunkowania polskich studiów nad przyszłością, chcemy teraz zrekonstruować cztery sposoby problematyzowania granic socjologicznej wyobraźni dotyczące przyszłości pochodzące z lat 70 . XX w. Skupiamy się przy tym na ich społecznie uwarunkowanej epistemologii. Innymi słowami, uprawiamy coś, co jeden z dalej omawianych autorów określał mianem historycznej „metaprognostyki” (Rolbiecki 1972: 52). Pod tym kątem zestaw wybranych przykładów, choć selektywny, odsłania charakterystyczne dla ówczesnej futurologii rozumowania na temat jej roli oraz orientacji ku przyszłości. Przedstawiane autorskie koncepcje nie służą portretowi intelektualno-biograficznemu, lecz udokumentowaniu zróżnicowanych prób (prze)definiowania porządków temporalnych.

\section{Futurolog jako ekspert teraźniejszości przyszłej: Prognozowanie Jana Szczepańskiego}

Jan Szczepański (1913-2004) znacząco przyczynił się do tego, że w końcu lat 60. i na początku 70. dyskusja na temat badań prognostycznych „W Polsce rozwija się szerokim frontem” (Szczepański 1974: 13). Aktywnie uczestniczył w przygotowaniach wspomnianej konferencji w Tardzie, 
utworzeniu Komitetu „Polska 2000”, a jako przewodniczący Międzynarodowego Stowarzyszenia Socjologicznego (ISA) współorganizował zjazd w bułgarskiej Warnie w 1969 r. poświęcony kwestiom prognozowania i planowania, który był okazją do wymiany intelektualnej ponad podziałami ideologicznymi.

Podejście Szczepańskiego stanowi przykład socjologicznej aktywności prognostycznej o intencji praktycznej. Rola prognostyki miała polegać na wychowaniu obywatelskim i ideologicznym. Tak rozumiana futurologia mogła się wpisać w oficjalna, marksistowską koncepcję aktywnego udziału nauk społecznych w przebudowie społeczeństwa. Dopiero z czasem władze polityczne w PRL zdały sobie sprawę, że mimo odgórnie ustalanych tematów badań prognostycznych spełnienie tej roli niekoniecznie przyczyniło się do wzmocnienia podstaw teoretycznych marksizmu-leninizmu (Bielecka-Prus 2011: 753-755).

Zakładając przyśpieszone tempo i charakter zmian społecznych w Polsce Ludowej po okresie stalinowskiej industrializacji oraz względnie stabilną sytuację międzynarodowa, futurologia miała przyczynić się do jakościowego przesunięcia ciężaru socjalistycznej polityki modernizacyjnej w kierunku „mózgów, kwalifikacji, wiedzy i organizacji [...] [oraz] wielk[iej] prac[y] uczenia narodu myślenia o przyszłości budowanej przez każdego obywatela na każdym stanowisku" (Szczepański 1971b: 137). Przede wszystkim namysł nad technikami prospekcyjnymi miał zastapić odwoływanie się do doświadczeń historycznych przy podejmowaniu decyzji życiowych i politycznych, i tym samym przyczynić się do udoskonalenia „układu kierowniczego" (Szczepański 1974: 18), czyli systemu planowania i sprawowania władzy. O ile jednak poprawa sposobów podejmowania decyzji wydawała się Szczepańskiemu możliwa, o tyle w społeczeństwie będącym z założenia układem kierowanym centralnie musiał uznać, że prognozy nie mogły dotyczyć ani zmian personalnych, ani instytucjonalnych w samym układzie kierowniczym (Sułek 2011b: 252).

Dlatego pytał, czy futurologia nie powinna skupiać się po prostu na analizie planów perspektywicznych oraz ocenie ich realności. Wyrażając zasadnicze wątpliwości co do tej ostatniej, Szczepański (1967: 98) zaprzeczał funkcjonowaniu doskonałego monocentryzmu, działającego wedle planów przypominających rozkłady jazdy pociągów (Ossowski 1967: 95). Futurologia, mimo podobnych korzeni ideowych, od cybernetycznego planowania i utopii miała się odróżniać orientacją empiryczną: „,chodzi jej nie o skonstruowanie modelu społeczeństwa ulepszonego, lecz społeczeństwa rzeczywistego" (Szczepański 1967: 100). 
Szczepański zakładał zatem, że analiza socjologiczna, która zajmuje się inwentaryzacją składowych danej struktury społecznej, elementów trwałych i zmiennych oraz mechanizmów ich działania, może dojść „do opisu przyszłego stanu społeczeństwa” (Szczepański 1967: 100). Jedyną zagadkę stanowiły sprzężenia zwrotne i nakładające się na siebie zdynamizowane, ale niesynchroniczne układy - od układu kierowniczego, przez ekologiczno-przestrzenne, demograficzne, do spontanicznych grup nieformalnych i procesów kreatywności artystycznej (Szczepański 1974: 18, 30f.). Tak „stemporalizowanej” (Luhmann 1980) mozaiki społecznej, której zmienność kontrolował nie ruch dialektyczny ani decyzja planisty, lecz złożona dynamika różnych układów czasowych, futurologia nie mogła opisać jednostkowej wizji, lecz tylko skoordynowaną współpracą ekspertów z różnych dziedzin i metod. W kontekście powstającego w 1970 r. biurokratycznego systemu specjalistycznych studiów prognostycznych9 Szczepański zdefiniował ich nadrzędny cel ambitnie, jako „uporządkowany obraz całości społeczeństwa” (Szczepański 1974: 13), co odpowiadało politycznym oczekiwaniom wobec teorii „rozwiniętego społeczeństwa socjalistycznego".

Cel urzeczywistnienia jednej pryncypalnej wizji społeczeństwa socjalistycznego do roku 1990 odsłania - niezależnie od oczywistej porażki realizacyjnej i mimo dynamiki zakładanej zarówno w marksistowskiej teorii postępu, jak i w zarysowanej koncepcji Szczepańskiego - wyobraźnię dotycząca przyszłości w kategoriach ostatecznie zamkniętej, uporządkowanej struktury. Przewidywaniom Szczepańskiego towarzyszyło założenie o trwałości klas społecznych jako głównych form stratyfikacji polskiego społeczeństwa do 2000 r., chociaż zarazem stwierdzał, że ich funkcja i wewnętrzne style życia ulegna pluralizacji (Szczepański 1974: 22). Lokalizował ostateczna granicę przewidywalności w społecznych „mikroformach” (Szczepański 1974: 30), małych grupach ulegających zmianie spontanicznej. Niemniej zauważał, w eseju podejmującym kwestię człowieka XXI w., że „[r]ozbicie struktur społecznych i rozbicie struktur myślenia jest znacznie trudniejsze niż rozbicie struktury atomu" (Szczepański 1971a: 25). Z tego wyłania się orientacja na przyszłość, którą można opisać bardziej w kategoriach dookreślania nadchodzącej - niemal deterministycznie - przyszłości niż ukazywania aktualnie możliwej wielości wariantów ${ }^{10}$. Przyszłość,

${ }^{9}$ Uchwała nr 150 Rady Ministrów z. dnia 17 września 1970 r. w sprawie wprowadzenia systemu prognoz jako podstawy do opracowywania planów 5-letnich i planów perspektywicznych (Monitor Polski Nr. 34, poz. 266, \$ 8, str. 514) zobowiązała ministerstwa, instytucje naukowe, Komisję Planowania oraz PAN do skoordynowanej pracy nad tematycznymi prognozami w horyzoncie $1990 \mathrm{r}$.

${ }^{10}$ Posługujemy się rozróżnieniem między present future a future present rozwiniętym przez Luhmanna (1976). 
o która prognozom tym chodziło, to przyszła teraźniejszość, ,aktualność jakiejś przyszłej daty" (Szczepański 1989: 9).

\section{Futurolog jako metodyk: Prognozy w empirycznej socjologii Stefana Nowaka}

Na kongresie futurologicznym w maju 1967 r. Stefan Nowak (19241989) stwierdził, że za deklaracjami futurologów o naukowym obiektywizmie kryją się różne „typ[y] idealn[e] nastawienia wobec zagadnienia prognozy przyszłości” (cyt. za Rażniewski et al. 1967: 91). Nie przywoławszy (przynajmniej w udokumentowanej części dyskusji) typologii Ossowskiego, zaproponował własną, w której wiedza o przyszłości stanowiła zmienna postaw epistemologicznych. Choć w tamtym kontekście Nowakowi chodziło o krytykę dyskutowanego modelu przyszłej kultury socjalistycznej, to wyłaniająca się z niej koncepcja przyszłości polega na innej orientacji temporalnej niż koncepcja Szczepańskiego.

Widać to w założonej przez Nowaka roli futurologa. Posługiwał się przeciwstawieniem dwóch typowych postaci: astronoma, który na podstawie informacji o procesach i sytuacjach wyjściowych niezależnych od niego przewiduje „tok zdarzeń przyszłych” (tamże); oraz gracza będącego częścią układu, który to układ stara się poznać, by realizować w nim swoje cele. Przewidywanie w ramach drugiej postawy nie jest kwestią mniejszego lub większego zasobu informacji, lecz mniejszych lub większych „stopni swobody” (tamże). Przy czym ani termin „gracz”, ani „stopnie swobody” nie były rozumiane jak w teorii gier i matematyce. Chodziło Nowakowi o to, by zwracać uwagę na często ubieraną w prognozy rzekomo samoistnych trendów „inżynierię społeczno-kulturową” (tamże: 93). Wytknął futurologom, że - usiłując „obiektywnie” przewidywać - właściwie proponuja całe systemy wartości i że za mało badają ograniczenia w immanentnych strukturach układu wyjściowego, powiązaniach funkcjonalnych, przeoczając wzajemne niezależności jego elementów. Wypowiadając się w dyskusji o prognozach rozwoju kultury socjalistycznej, ilustrował tę sprzeczność między obiektywizmem a wartościowaniem na przykładzie sprzecznych wartości w debatowanym modelu kultury socjalistycznej. Na gruncie marksistowskiej teorii postępu zarówno miała być ona egalitarna, jak i służyć maksymalizacji wydajności gospodarczej, co uważał za nie do pogodzenia (tamże). Metodologicznie z jednej strony Nowak apelował o przyznanie się do postawy „gracza” uznającej wartościowania (a zatem problem odpowiedzialności) za główną operację futurologów. Z drugiej strony, w zakresie 
empirii społecznej nawoływał do badania zakresu alternatywnych biegów rzeczy, na które pozwalały ograniczenia immanentnych struktur i powiązań funkcjonalnych społeczeństwa socjalistycznego. Posługując się figurą gracza, odrzucał koncepcję ,inżynierii społecznej”, zakładając, że „partnerzy tej zabawy też są podmiotami myślącymi, mającymi swoje cele, które należałoby uwzględnić w planowaniu społecznym" (tamże: 94).

Do postawy astronoma wobec kwestii przewidywalności przyszłości sam Nowak zbliżał się trochę jako teoretyk i metodolog nauk społecznych (por. Nowak 1976). Natomiast jego aktywny udział w dyskusji w Tardzie, a później w latach 70. na konferencjach Komitetu „Polska 2000” oraz w konwersatorium „Doświadczenie i Przyszłość” (DiP) należy raczej traktować jako udział w grze (dalekiej wszak od zabawy). Fora te w praktyce funkcjonowały jako miejsce wymiany intelektualnej o stanie i perspektywach polskiego społeczeństwa, stając się - by pozostać w tej metaforyce - planszami interakcji dla intelektualistów bliskich władzy oraz socjologów krytycznie nastawionych wobec bieżącej sytuacji politycznej w PRL. Właśnie pod kątem kryzysu systemu władzy na początku lat 80. uaktywniała się u Nowaka postawa prognostycznego gracza, który wyniki badań opinii wykorzystywał do ukazania i wartościowania alternatyw rozwojowych (Nowak 2004 [1983], Grabowska, Sułek 2009: 20). Tuż po ogłoszeniu stanu wojennego, wraz z innymi członkami opozycyjnego Konwersatorium DiP napisał raport pod tytułem Hipotetyczne scenariusze przemian (Gotowski et al. 1982). Wydanie go nakładem Komitetu „Polska 2000”, które spotkało się z ostrą krytyką ze strony organizacji partyjnej PAN, pokazuje, że debaty o prognozach w tej kryzysowej sytuacji mniej niż syntetycznemu obrazowi całego społeczeństwa służyły konfrontacji różnych interpretacji oraz światopoglądów.

Epistemologiczna zapowiedź tego można widzieć w tym, co napisał Nowak w obliczu względnej nowości futurologii na początku lat 70. Wtedy omawiał ja jako jedną $z$ odrębnych technik budowania prognoz w podręczniku metodologii, a więc jako element wiedzy kanonicznej dla studentów „tak zwanej socjologii empirycznej” (Nowak 1970: 9). Chciał ich uczyć „postawy gracza” czy „astronoma”? Wskazując na rosnąca potrzebę stosowania wiedzy socjologicznej w praktyce politycznej i ekonomicznej, Nowak umieścił futurologię obok innych technik prospekcji (dedukcji, probabilistycznych oszacowań, ankietowych badań zamiarów, ekstrapolacji trendów itp.) ${ }^{11}$. Porównał ją - podobnie jak Szczepański - ze względu na

${ }_{11}$ Warto zwracać uwagę na to, że w kompozycji podręcznika z 1970 r. wątek prospekcji - zgodnie z Comte'owską tezą spełnienia nauk społecznych w umiejętnościach prognostycznych - stanowi 
dłuższe horyzonty czasowe, $z$ utopiami, ideologiami oraz teoriami społecznego rozwoju, twierdząc, że

[n]owym elementem, jaki do tych zagadnień wnosi tzw. „futurologia”, jest próba nadania tym prognozom postaci maksymalnie kontrolowalnej i formułowanie twierdzeń o przyszłych losach społeczeństw czy też poszczególnych dziedzinach życia społecznego [...] w sposób maksymalnie zasadny. [...] Cechą charakterystyczną współczesnej 'futurologii' jest to, że formułuje prognozy „średniego zasięgu”, z reguły nie wykraczające poza lat 30 (rok 2000 stał się symboliczna granicą futurologicznych rozważań) (Nowak 1970: 451).

Właściwym, to znaczy najbardziej naukowym narzędziem futurologii była według Nowaka ekstrapolacja trendów i formułowanie hipotez warunkowych, mających często charakter samospełniającej się przepowiedni (Nowak 1970: 453-461). Kluczowym modusem technik prospekcji ma być zarysowanie wielu wariantów - których ilość „podlega nie tylko prawom kombinatoryki” (Nowak 1970: 457 f.). Przyszłość futurologii zatem nie jest przyszłościa obliczalną, lecz „rozpiętośc[ia] między możliwym minimum i maksimum. Tym samym [futurologia] określa dla danego trendu granice realnych możliwości lub inaczej granice socjotechnicznego manewru, poza którymi plan staje się utopią" (Nowak 1970: 459). Prospekcja nie polega tu na określeniu wizji podbudowanej autorytetem naukowym, ma raczej odsłonić granice i „ukryte” (Nowak 1970: 460) konsekwencje aktualnych decyzji planistyczno-politycznych. Mimo że Nowak powtórnie podkreśla dążenie do rygorystycznej naukowości, poleca (w podręczniku socjologii empirycznej!) futurologom sięgać do fikcyjnych scenariuszy fantastyki i utopii - po to, by nie stracić „ideologicznej wyobraźni” (Nowak 1970: 460 f.) dla problemów nieobliczalnych statystycznie.

\section{Futurolog jako epistemolog przyszłości: „Prognozologia” Waldemara Rolbieckiego}

Stosunkowo krótka faza koniunktury futurologii w Polsce od połowy lat 60. do końca lat 70. generowała, obok samych prognoz, także refleksje nad przewidywalnościa jako taką. Dziś raczej mało znany naukoznawca

punkt kulminacyjny. W wydaniu z 1985 r. jest natomiast rozproszony, a futurologia stanowi część socjologii stosowanej (Nowak 1985: 462). 
Waldemar Rolbiecki (1927-2002) rozwijał ten drugi, „metaprognostyczny" (Rolbiecki 1972: 52) wątek, zapowiadając - na razie bez powodzenia, jak się wydaje - powstanie nowej dyscypliny naukowej zwanej „prognozologia" (Rolbiecki 1967: 241, 1970). Ten pomysł wyrastał z aktywności w obszarze organizacji i planowania nauki w PAN. Ukończywszy studia z zakresu pedagogiki, filozofii i socjologii, Rolbiecki uczęszczał m.in. na konwersatoria Kazimierza Ajdukiewicza i Tadeusza Kotarbińskiego, a po usunięciu z uniwersytetu w 1951 roku przeszedł do PAN, gdzie w latach 60. pełnił funkcję kierownika Zespołu Planu Perspektywicznego Rozwoju Nauki Polskiej (Skarbek 2003). Przeszedłszy w 1968 r. do pionu naukowego jako pracownik Zakładu Historii Nauki i Techniki, Rolbiecki zajmował się prognozowaniem z perspektywy prakseologicznej. W jego tekstach przyszłość staje się wręcz przedmiotem wiedzy ${ }^{12}$, a futurolog występuje w roli epistemologa. Jak stwierdza Rolbiecki (1967: 280-281), pozwoliło to omijać wiążące ramy ideologiczne oraz ryzyko propagandowego wykorzystania konkretnych prognoz. Refleksja prognozologiczna krąży zatem wokół problemu sprawcz̧ości, wyraźnie przeciwstawiając się refleksji nad sprawnościq - tematem kwitnących wówczas studiów o organizacji, zarządzaniu i „socjotechnice” (Rolbiecki 1972: 43).

Definicja Rolbieckiego dokonuje uprzedmiotowienia przyszłości. Nie określa ona ani temporalnego horyzontu, ani przyszłych rzeczy, lecz „ewentystycznie” obejmuje „coś złożonego z takich zdarzeń, które dopiero się zdarza, czyli zajdą" (tamże 1972: 42). Nie chodzi zatem o przewidywanie trendów rozwojowych, lecz o rozmaite zdarzenia: zdarzenia statyczne i proceduralne, proste i złożone, wcześniejsze i późniejsze, krótsze i dłuższe, krajowe i międzynarodowe, a także zdarzenia humanistyczne i nie-humanistyczne (tamże 1972: 42-45). Na tej podstawie Rolbiecki wyobrażał sobie granice przewidywalności jako model koncentrycznych kół ułożonych wokół sprawczości ludzkiej.

Jądrem tego modelu są $(\alpha)$ świadomie podjęte decyzje ludzkie otoczone $(\beta)$ ich skutkami równocześnie niebędącymi decyzjami, o jeden krąg dalej $(\gamma)$ skutkami już dawno podjętych decyzji, a w ostatnim kręgu ( $\delta$ ) zdarzeniami niebędącymi ani czynami ludzkimi, ani ich skutkami. W tym „ergonicznym” modelu było wiec miejsce na tak zwaną przyszłość „,niegotową" lub otwarta ( $\alpha$ i $\beta$ ) oraz „gotową” ( $\gamma$ i $\delta$ ) - zamknięta, „bo nic już nie

\footnotetext{
12 Odwołujemy się do koncepcji epistemic things historyka nauki Hansa-Jörga Rheinbergera. Tak jak w laboratoryjnej biologii molekularnej przedmiot badań futurologii, czyli przyszłość, cechuje nieredukowalna niejasność - „w swojej obecności eksperymentalnej są [one] w pewnym sensie nieobecne" (Rheinberger 1994: 409, Surman 2014: 54).
} 


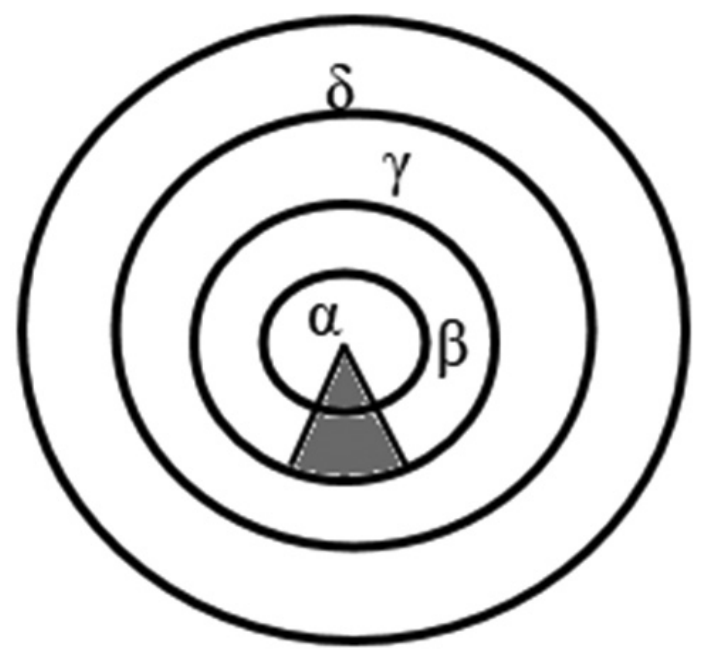

Strefa sensownej planowalności przyszłości (za Rolbiecki 1972: 52)

brakuje" (tamże 1972: 48), aby mogła zajść. Sensem tego modelu jest ukazanie, jaki mały wyimek przyszłości „niegotowej” (obszar szary na rysunku) stanowi strefę sensownego planowania (tamże 1972: 45-52).

Granice przewidywalności sięgaja jednak dużo dalej. Rolbiecki „wyznaj[e] pogląd, iż cała przyszłość (tj. wszelkie zdarzenia przyszłe) jest zasadniczo poznawalna" (tamże 1972: 49). Nie oznacza to, że przewidywania są trafne lub pewne. Natomiast także obszary nieplanowalne rządzą się zasadniczo poznawalnymi prawami. Zatem tylko przewidywania jeszcze niepodjętych decyzji ludzkich oraz ich skutków $(\alpha$ i $\beta$ ) wymagaja wyrafinowanej metodologii (tamże 1972: 50). W konkrety tych metod Rolbiecki nie wchodzi, jednak wyborem nielicznych przykładów wskazuje granice przewidywalności tam, gdzie dotykają one stosunków ludzi z przyrodą. Zakłada, że np. przy przemysłowym przetwarzaniu celulozy i powstałych w tym procesie odpadach, ciagi kauzalne nie pozwalaja rozdzielać zdarzenia na czyny i skutki (tamże 1972: 44). Jego tekst pokazuje trudność uchwycenia tej granicy, leżącej u podstaw prognozowania. Futurologia ta, z pozoru tak formalna, zachęca do włączania ciągle rzadkich wówczas wątków ekologicznych. $\mathrm{Na}$ ich podstawie, mimo zainteresowań metaprognostycznych, Rolbiecki formułuje też prognozę w istocie polityczną: ludzka sprawczość ingerująca w układy nieludzkie sprawia, że coraz trudniej przewidywać, bo „strefa prostych zależności się kurczy” (tamże 1972: 46). 


\section{Futurolog jako uczeń czarnoksiężnika: Prognozowanie kultury Andrzeja Sicińskiego}

W dyskusje o futurologii naukowej Andrzej Siciński zaangażował się w latach 60. i 70. jak żaden inny polski socjolog. Obszernego wkładu Sicińskiego w uzasadnienie (Siciński 1969), organizację (Siciński 1972), usystematyzowanie metodologiczne (Rażniewski, Siciński 1973, Siciński, Gzula 1976), usieciowienie międzynarodowe (Ganczew, Siciński 1975) oraz empiryczne stosowanie (Siciński 1975 [1973], Ornauer et al. 1976) studiów prognostycznych nie możemy w tym miejscu szczegółowo omawiać. Siciński gruntownie zapoznał się z zagraniczną literaturą prognostyczną, zanim socjolodzy polscy głośno o niej mówili. Oceniał możliwości przewidywania niejednoznacznie ${ }^{13}$, ale strategicznie apelował o własne polskie badania w odpowiedzi na globalna ,wojnę na prognozy” (Siciński 1967: 243). Można powiedzieć, że Siciński poprzez udział w międzynarodowym projekcie Images of the Year 2000, samodzielnie założony w 1969 r. Zespół Prognoz Społecznych w IFiS PAN (Tarkowska 1999) oraz w drugiej połowie lat 70. funkcję delegata do Światowej Federacji Studiów nad Przyszłością stał się rozpoznawalnym za granica reprezentantem polskiej futurologii. Przyczyniło się do tego zainteresowanie Sicińskiego rozwojem kultury, a w szczególności stylów życia, tematem, który wówczas w skali międzynarodowej debaty o futurologii był uważany za oryginalne podejście (Siciński 1973: 176, Masini 2001).

Połączenie socjologii kultury i badania opinii z prognozowaniem wywodził z Pracowni Żółkiewskiego, dla którego kultura była - wbrew materialistycznej teorii ścisłej zależności nadbudowy od praw rządzących baza - „sfer[a] uprzywilejowan[a] twórczości spontanicznej, a więc nieprzewidywalnej” (Żółkiewski 1967: 10). W kontekście deklaracji ówczesnych władz PRL o przejściu od etapu uprzemysłowienia do etapu zaspokojenia potrzeb konsumpcyjnych i kulturalnych zainstalowanie futurologii w tym miejscu było też strategicznie stosownym wyborem. Jednocześnie przewidywanie nadchodzących przemian kulturowych dało przestrzeń dla intuicji i wyobraźni przekraczającej empiryzm. Główną tezą prognostyczną Sicińskiego było naprężenie między tendencjami zróżnicowania i ujednolicenia: wraz z coraz powszechniejszym uwolnieniem ludzi od dominacji czynników ekonomicznych musi - twierdził - nastąpić większy pluralizm sty-

13 APAN, DWNS, II-73 367/41 194, b. p.: Siciński A. [1966]. Możliności naukowych dociekań prayszłości. Wspótczesne kierunki rozważań (Na prawach rekopisu), Komitet Badań nad Kulturą Współczesną PAN. 
lów życia, podczas gdy różnice klasowe się niwelują (Siciński 1975: 14-18). Daleki od interpretacji wprost optymistycznej, wskazującej na potencjał emancypacyjny i demokratyzację wyborów, Siciński zwracał też uwagę na niebezpieczeństwa. Nie wykluczał dezintegracji społecznej, alienacji i powstania nowych podziałów - np. pomiędzy „nomadycznymi” stylami życia otwartymi na mobilność i migracje a „osiadłymi” stylami życia, którym brak „upodobania do ruchliwości” (Siciński 1973: 181).

Istotna podstawa zarówno dla tych prognoz, jak i dla późniejszych badań empirycznych w ramach własnej koncepcji metodologicznej stylów życia, była naszym zdaniem koncepcja przyszłości Sicińskiego. Wyraźniej niż Nowak w swoich studiach nad przyszłością Siciński podkreślał, że ich wyróżniający element to „prognozy wariantowe” (Siciński 1972: 14). Alternatywność przyszłości, alternatywne style życia i koncepcja człowieka wybierającego homo eligens stały się motywem jego dalszej pracy (Siciński, Wemegah 1983). Futurologia zwracająca uwagę na możliwe alternatywy rozwojowe na przełomie lat 60. i 70. wydawała się Sicińskiemu konstruktywnym wkładem do planowania społecznego (Czerwiński 1969: 869). Jednak w 1979 roku na seminarium Komitetu „Polska 2000” ogłosił referat diagnozujący nieprzekraczalny już w ówczesnej Polsce Ludowej dystans między „społeczeństwem istniejącym i społeczeństwem pożądanym”"14. Referat ten może wyglądać jak zapowiedź późniejszego zaangażowania w Konwersatorium DiP i doradzanie Solidarności, ale też nadchodzącego rozczarowania prognozami.

Takiej kauzalności natomiast zaprzeczaja pojęcia czasu i przyszłości, które wyłaniają się z futurologii Sicińskiego. Jej orientacja temporalna polega na tym, „aby wziąć pod uwage, jak dzisiejsze cele i decyzje zostaną zaakceptowane poprzez przyszłe pokolenia" (Siciński 1972: 15). W Images of the Year 2000 ten pomysł brzmiał tak: ,We would like to know more about how the future enters, where it enters and how expectations and hopes mingle and blend in different groups and nations" (Ornauer et al. 1976: 7). W społeczeństwach centralnie planowanych przyszłość teoretycznie miała wchodzić twórczo w postaci planów (w systemach wolnorynkowych tylko korekcyjnie). Prognostycy mieli być innowatorami, którzy skłaniają decydentów do poszukiwania dotąd nieznanych rozwiązań (Siciński 1975 [1971]: 254). Siciński podkreślał, że prognozowanie „może sięgać dużo dalej niż planowanie (np. do zmian genetycznych lub biologicznych)" (Siciński 1972: 16).

${ }^{14}$ Siciński A. 1979. Spoteczৃeństwo istniejace a spoteczeńnstwo pożadane. Tezy do dyskusji (Referat na konferencje „Społeczeństwo mychownjace - rzeeczywistość i perspektyny”, Jabłonna, grudzień 1979 r., maszynopis powielany [w zasobach $\mathrm{BN}]$. 
Granice futurologicznej wyobraźni wyznaczało tylko pojawienie się „,ewentualnej istoty post-ludzkiej”' (Siciński 1973: 177).

Siciński zatem, zadając pytania futurologiczne, wypowiadał się nie tylko o istniejącym społeczeństwie monocentrycznym w Polsce Ludowej. Co wydaje się może ucieczką w daleką przyszłość, dotyka jednak istoty projektów modernizacyjnych i nowoczesności, również jej wariantu socjalistycznego. Sicińskiego pojęcie przyszłości charakteryzuje się refleksyjnością: ludzie przez innowacje technologiczne i interwencje w przyrodę, przez antycypowanie i świadome kształtowanie przyszłości, wywołuja siły, nad którymi nie są w stanie panować. Siciński zdaje się podsumował to swoimi wnioskami z badań nad społecznymi reakcjami na katastrofę w Czernobylu w 1986 r.: ludzie zdobywający wiedzę o przyszłości są skazani na „nieporadnoś[ć] Ucznia Czarnoksiężnika, nadmiern[a] pewnoś[ć] siebie ludzi techniki, niepewnoś[ć] ludzi wiedzy i ludzi «mass mediów»” (Siciński 1989: 9).

\section{/// Konkluzja}

Cztery omawiane konceptualizacje przyszłości w socjologii polskiej powstały przed niemal półwieczem w warunkach ostatniego podrywu modernizacyjnego PRL z jednej, a pierwszymi instytucjonalizacjami globalnych niepokojów o ,granice wzrostu” z drugiej strony. Socjologiczne przewidywania były spętane ograniczeniami „monocentrycznego” (Ossowski) układu politycznego, choć sama futurologia nie była na jego usługach.

Oczywiście okazała się niezdolna - jak prawie cała polska socjologia tamtego czasu - do wyobrażenia sobie wyjścia poza socjalistyczny porządek, $i$ to tuż przed jego potężnym kryzysem, a potem całkowitym rozpadem (Sułek 2011b). Była to więc futurologia wprost nieskuteczna, jednak w oczach przywołanych powyżej autorów stanowiła poszerzające wyobraźnię ćwiczenie intelektualne. Proponujemy odzyskać tę historyczną wartość polskiej futurologii naukowej nie tyle przez pytanie o to, co zdołała przewidzieć (a takich kwestii szczegółowych zebrałby się pokaźny katalog), lecz o to, jak to robiła. Futurolog jako ekspert w rozumieniu Szczepańskiego wyobrażał sobie przyszłość jako przyszłą teraźniejszość, którą w możliwie pełnym obrazie ukazuje. Metaprognostyka Rolbieckiego zakładała zasadniczą przewidywalność przyszłości, przy czym futurolog miał wskazać na historycznie zmniejszający się zakres planowalności. Natomiast koncepcje Nowaka i Sicińskiego z różnych punktów wyjścia nalegały, by wyobrażać sobie przyszłość jako zakres wielu aktualnie możliwych i ostatecznie niepewnych przyszłości. 
Tamta futurologia powstawała w otwartym horyzoncie przyszłości, pomiędzy pierwszym lotem człowieka w kosmos, jego triumfalną wizytą na Księżycu, a katastrofą w Czarnobylu. Dziś, po powierzchownie wyśmianym, a zarazem głęboko zinternalizowanym przekonaniu o „końcu historii” po roku 1989, wchodzimy chyba w zupełnie inny reżim czasowy - w historie końca. Jego futurologia dopiero się rodzi, choć przybiera już bardzo wymierne postaci, jak np. obliczenia skali globalnych spustoszeń wywołanych ociepleniem klimatu o 2 stopnie Celsjusza. To już nie tylko intelektualna moda, ale egzystencjalna konieczność sugeruje, że „futurologiczne" ćwiczenia antropocenicznej wyobraźni socjologicznej są dziś chyba ważniejsze niż kiedyś.

Bibliografia:

/// Andersson J. 2012. The Great Future Debate and the Struggle for the World, „The American Historical Review”, nr 5, s. 1411-1430.

/// Andersson J. 2018. The Future of the World. Futurology, Futurists, and the Struggle for the Post Cold War Imagination, Oxford University Press.

/// Baade F. 1962. Rok 2000. Ku czemu zmierza świat?, PWE.

/// Becht L. 2017. From Euphoria to Frustration: Institutionalizing Prognostic Research in the Polish People's Republic, 1969-76, „Acta Poloniae Historica”, nr 116, s. 277-299.

/// Beckert J. 2016. Imagined Futures. Fictional Expectations and Capitalist Dynamics, Harvard University Press.

/// Bell D. 1966. Dwanaście sposobów przewidywania w naukach spotecznych (do użytku służbowego), PAN Ośrodek Planowania i Koordynacji Badań Naukowych.

/// Bell D. 1970. The Post-Industrial Society: Technocracy and Politics, [w:] Transactions of the Seventh World Congress of Sociology, Varna, September 14-19, 1970, vol. I, red. ISA, The Bulgarian Academy of Sciences Publishing House, s. $15-36$.

/// Bielecka-Prus J. 2011. The Social Roles of Polish Sociologists after 1945, „Comparative Sociology", nr 5, s. 735-765. 
/// Catanus A. 2015. Official and Unofficial Futures of the Communist System. Romanian Future Studies between Control and Dissidence, [w:] The Struggle for the Long-Term in Transnational Science and Politics. Forging the Future, red. J. Andersson, E. Rindzevičiūtè, Routledge, s. 170-194.

/// Christian D. 2011. Maps of Time. An Introduction into Big History, The University of California Press.

/// Chruszczow N. 1961. O programie Komunistycznej Partii Zwiazku Radzieckiego, referat wygtoszony na XXII Zježdzie KPZR 18 października 1961 r., „Nowe Drogi”, nr 11, s. 95-182.

/// Crutzen P.J. 2002. Geology of mankind, „Nature”, nr 415, s. 23.

/// Czerwiński M. 1969. Wprowadzenie w futurologię. Recenzja ksiażki Andrzeja Sicinskiego: Prognozy a nanka, Warszawa: KiW 1969, „Nowe Ksiąziki”, nr 13, s. 869-870.

/// Czerwiński M., Pawełczyńska A., Porębski M., Siciński A., Strzelecki J., Żółkiewski S. 1967. Elementy præyszłościowego modelu kultury socjalistycznej w Polsce, „Kultura i Społeczeństwo”, nr 4, s. 49-66.

/// De Jouvenel B. 1966. O przewidywaniu (W aneksie skerót szlkicu Emila Fagueta "Jaki bedzie dwudziesty wiek.") (do użytku służbowego), PAN Ośrodek Planowania i Koordynacji Badań Naukowych.

/// Domańska E. 2014. Historia ratownicza, „Teksty Drugie”, nr 5, s. 12-26.

/// Etzemüller T. 2017. Social Engineering, Version: 2.0. http://docupedia.de/ zg/Etzemueller_social_engineering_v2_de_2017; dostęp: 16.07.2018.

/// Falewicz J., red. [1970]. Zewnetrzne i wewnetrzne uwarunkowania zjawisk patologii spotecznej w Polsce w świetle nadestanych wypowiedzi, Ossolineum.

/// Filipkowski P. 2017. Back to future's past. Andrzej Sicinski’'s scientific futurology, „Acta Poloniae Historica”, nr 115, s. 267-271.

/// Foucault M. 1976. Überwachen und Strafen. Die Geburt des Gefängnisses, Suhrkamp.

/// Fourastié J. 1954. Die große Hoffnung des zwanzigsten Jahrbunderts, Bund.

/// Ganczew P., Siciński A., red. 1975. Problemy prognozowania w krajach socjalistycznych, Ossolineum. 
/// Gordon T.I., Helmer O. 1965. Prognozy wieloletnie (Próba præ̨ewidywania przysz̧łościq metoda delficka) (do użytku służbowego), PAN Ośrodek Planowania i Koordynacji Badań Naukowych.

/// Gotowski B., Kapuściński R., Nowak S., Regulski J., Siciński A., Trzeciakowski W., Gotowski W. 1982. Hipotetyczne scenariusze przemian ekonomicznych, spotecznych i politycznych w Polsce 1982/83, Komitet Badań i Prognoz „Polska 2000" przy Prezydium PAN.

/// Grabowska M., Sułek A. 2009. Stefan Nowak jako badacz społecreństwa polskiego, [w:] S. Nowak, O Polsce i Polakach. Prace rozproszone 1958-1989, Wydawnictwa UW, s. 11-28.

/// Harari Y.N. 2016. Homo deus: A brief history of the future, Harvill Secker.

/// Hartog F. 2015. Regimes of historicity. Presentism and experiences of time, Columbia University Press.

/// Hölscher L. 1999. Die Entdeckung der Zukunft, Fischer.

/// Hölscher L. 2017. Theoretische Grundlagen der historischen Zukunftsforschung, [w:] tegoż, Die Zukunft des 20. Jahrhunderts: Dimensionen einer historischen Zukunftsforschung, Campus, s. 7-38.

/// Karpiński A. 2001. Studia nad przyszłościq na świecie i w Polsce (doświadczenia i wnioski), „Biuletyn Polska 2000 Plus”, nr 2, s. 9-23.

/// Kiecko E. 2018. Przyszłość do z̧budowania. Futurologia i architektura w PRL, Fundacja Bęc Zmiana.

/// Kolář P. 2016. Der Poststalinismus. Ideologie und Utopie einer Epoche, Böhlau.

/// Komitet Prognoz „Polska w XXI Wieku” przy Prezydium PAN, red. 1999. Studia nad przyszłościa w Polsce w pracach Komitetu Prognoz, „Polska w XXI wieku". Komitet i jego twórcy (w 30-lecie powstania Komitetu) 1969-1999, Elipsa.

/// Kurczewski J. 2009. Obraz świata w roku 2000 i co z tego wynikto, [w:] Socjologia i Sicinski. Style życia, społeczeństwo obywatelskie, studia nad przyszłościa, red. P. Gliński, A. Kościański, IFiS PAN, s. 67-84.

/// Luhmann N. 1980. Temporalisierung von Komplexität. Zur Semantik neureitlicher Zeitbegriffe, [w:] tegoż, Gesellschaftsstruktur und Semantik. Studien zur Wissenssoziologie der modernen Gesellschaft, Suhrkamp, s. 235-300.

/// Luhmann N. 1976. The Future Cannot Begin. Temporal Structures in Modern Society, ,Social Research”, nr. 1, s. 130-152. 
/// Mallard G., Lakoff A. 2011. How Claims to Know the Future Are Used to Understand the Present: Techniques of Prospection in the Field of National Security, [w:] Social Knowledge in the Making, red. C. Camic, N. Gross, M. Lamont, Chicago University Press, s. 339-378.

/// Masini B. 2001. Preface. Futures Studies and the WSFS in Central and Eastern Europe mainly in the period between 1970 and 1990, [w:] Futures Studies in the European Ex Socialist Countries, red. E. Nováky, V.R. Varga, M.K. Köszegi, Futures Studies Centre Budapest University of Economic Science and Public Administration, s. 10-14.

/// Meadows D., Meadows D., Zahn E., Milling P. 1973. Granice wærostu, tłum. W. Rączkowska, S. Rączkowski, PWE.

/// Meynaud J. 1957. Paryskie spotkanie, „Kultura [Paryż]”, nr 1-2, s. 91-104.

/// Minois G. 1996. Histoire de l'avenir. Des prophètes à la prospective, Fayard.

/// Nowacki W. 1985. Notatki autobiograficzne, PWN.

/// Nowak S. 1970. Metodologia badań socjologicznych. Zagadnienia ogólne, PWN.

/// Nowak S. 1976. Inductive Inconsistencies and the Problems of Probabilistic Predictions, [w:] tegoż, Understanding and Prediction. Essays in the Methodology of Social and Behavioral Theories, D. Reidel Publishing, s. 228-253.

/// Nowak S. 1985. Metodologia badań socjologicznych, PWN.

/// Nowak S. 2004 [1983]. Postawy, wartości i aspiracje społeczeństwa polskiego przestanki do prognozy na tle przemian dotychczasowych, [w:] tegoż, Społeczeństwo polskie czasu kryzysu, Wydział Filozofii i Socjologii UW, s. 337-380.

/// Nycz R. 2014. Wstep: Humanistyka præysztości, „Teksty Drugie”, nr 5, s. 7-11.

/// Ornauer H., Wiberg H., Siciński A., Galtung J., red. 1976. Images of the World in the Year 2000. A Comparative Ten Nations Study, Mouton.

/// Ossowski S. 1967. Koncepcje ładu spotecznego i typy przemwidywań [1959], [w:] tegoż, Drieła, tom IV: O nauce, PWN, s. 173-193.

/// Paczkowski A. 2005. Pót wieku driejón Polski, 5. wyd., PWN.

/// Plaggenborg S. 2006. Experiment Moderne: Der sonjetische Weg, Campus.

/// Rażniewski A., Siciński A., red. 1973. Elementy metodologii prognozowania społecrnego, Ossolineum. 
/// Rażniewski A. et al. 1967. Dyskusja, „Kultura i Społeczeństwo”, nr 4, s. 85-131.

/// Rheinberger H.-J. 1994. Experimentalsysteme, Epistemische Dinge, Experimentalkulturen. Zu einer Epistemologie des Experiments, „Deutsche Zeitschrift für Philosophie", nr 3, s. 405-417.

/// Rindzeviciūtè E. 2016. A struggle for the soviet future. The birth of scientific forecasting in the Soviet Union, „Slavic Review”, nr 1, s. 52-76.

/// Rocca G.L. 1981. „A Second Party in Our Midst”: The History of the Soviet Scientific Forecasting Association, „Social Studies of Science”, nr 2, s. 199-247.

/// Rolbiecki W. 1967. Badania prognostyczne - prognozologia - futurologia (W qwiazku z sympozjum prognostycznym w Pradze w dn. 21-24 II 1967 r.), „Nauka Polska”, nr 4, s. 95-99.

/// Rolbiecki W. 1969. Prognostication and Prognoseology. On the need of systematic inquiries about the prognostic activity of man, [w:] Mankind 2000, red. R. Jungk, J. Galtung, Universitetsforlaget/Allen \& Unwin, s. 278-285.

/// Rolbiecki W. 1970. Præewidywanie przyszłości, Wiedza Powszechna.

/// Rolbiecki W. 1972. Ergoniczny aspekt przyszłości. Cztery rodzaje zdarzeñ przysztych, „Zagadnienia Naukoznawstwa”, nr 1, s. 42-53.

/// Sabrow M. 2009. Chronos als Fortschrittsheld: Zeitvorstellungen und Zeitverständnis im kommunistischen Zukunftsdiskurs, [w:] Die Spur des Sputnik. Kulturhistorische Expeditionen ins kosmische Zeitalter, red. I.J. Polianski, M. Schwartz, Campus, s. 119-134.

/// Schulze Wessel M. 2018. Der Prager Frübling. Aufbruch in eine neue Welt, Reclam.

/// Scranton R. 2015. Learning to Die in the Anthropocene. Reflections on the End of a Civilization, City Light Books.

/// Secomski K. 1962. Problemy planowania perspektywicznego, [w:] Polityka gospodarcza Polski Ludowej, t. 2, red. J. Główczyk, J. Gordon, J. Kofman, J. Pajestka, Książka i Wiedza, s. 511-579.

/// Secomski K. 1970. Badania prognostyçne w Polskiej Akademii Nauk, „Nauka Polska”, nr 1, s. 9-21.

/// Secomski K. 1971. Prognostyka, Wiedza Powszechna. 
/// Seefried E. 2015. Zukünfte. Aufstieg und Krise der Zukunftsforschung 19451980, Walter de Gruyter.

/// Seefried E. 2017. Der kurze Traum von der steuerbaren Zukunft: Zukunftsforschung in West und Ost in den ,langen” 1960er Jahren, [w:] Die Zukunft des 20. Jabrhunderts. Dimensionen einer historischen Zukunftsforschung, red. L. Hölscher, Campus, s. 179-220.

/// Siciński A. 1967. Polskie studia ,futurologicæne”, „Kultura i Społeczeństwo", nr 2, s. 243-244.

/// Siciński A. 1969. Prognozy a nauka, Książka i Wiedza.

/// Siciński A. 1972. Future research, „Polish Perspectives”, nr 1, s. 10-16.

/// Siciński A. 1973. Perspektyny przemian kulturowych, [w:] Perspektywy XXI wieku. Szkice futurologicz̧ne, red. E. Drożdż, Książka i Wiedza, s. 176-183.

/// Siciński A. 1975. O ogólnych tendencjach prz̨emian kulturowych, [w:] tegoż, Dris i jutro kultury polskiej, Książka i Wiedza, s. 13-40.

/// Siciński A. 1975 [1971]. O roli eksperta w procesie podejmowania decyzji, [w:] tegoż, Džiś i jutro kultury polskiej, Książka i Wiedza, s. 250-258.

/// Siciński A. 1975 [1973]. Przyszłość kultury a myślenie prospek.tywne, [w:] tegoż, Driś i jutro kultury polskiej, Książka i Wiedza, s. 259-268.

/// Siciński A. red. 1989. Nazajutræ... Reakcje spoteczeństwa polskiego na katastrofe w Czarnobylu, PTS/IFiS PAN.

/// Siciński A. 1996. Driałalność wydawnicza i badawcza a polityczne „zawirowania” w socjalizmie. W zwiqzke z losami „Kultury i Spokeczensstwa” w latach 19601968 - relacja ₹ „obserwacji uczestniczqcej”, „Kultura i Społeczeństwo”, nr 3, s. 99-104.

/// Siciński A., Gzula J. 1976. Problemy Metodologii Prognozowania, Książka i Wiedza.

/// Siciński A., Wemegah M. 1983. Alternative Ways of Life - Their Impressive Present and Uncertain Future, [w:] tychże, Alternative Ways of Life in Contemporary Europe, The UN University, s. 3-12.

/// Skarbek J. 2003. Waldemar Rolbiecki (1927-2002), „Kwartalnik Historii Nauki i Techniki”, nr 3-4, s. 191-202. 
/// Sommer V. 2016a. Forecasting the Post-Socialist Future. Prognostika in Late Socialist Czechoslovakia, 1970-1989, [w:] Forging the future. Transnational perspectives on the history of prediction, red. J. Andersson, E. Rindzevičiūte, Routledge, s. $144-168$.

/// Sommer V. 2016b. Scientists of the world, unite! Radovan Richta's theory of a Scientific and Technological Revolution, [w:] Science Studies during the Cold War and beyond. Paradigms defected, red. E. Aronova, Palgrave, s. 177-205.

/// Sommer V. 2017. From socialist post-industrialism to market economy: Futurology in Czechoslovakia (1960s-1980s), „Bohemia”, nr 1, s. 55-81.

/// Steffen W. et al. 2015. The Trajectory of the Anthropocene: The Great Acceleration, „The Anthropocene Review”, nr 1, s. 81-98.

/// Strzelecki J. 08.07.1967. Kilka glos o planie. „Polityka”, s. 1, 6-7.

/// Sułek A. 2011a. „Do Ameryki!”. Polscy socjologowie w Stanach Zjednoczonych po 1956 roku i rožnój socjologii empirycznej w Polsce, [w:] tegoż, Obrazy z. ¿ycia socjologii w Polsce, Oficyna Naukowa, s. 96-141.

/// Sułek A. 2011b. O nieprzemidywalności rewolucji. Dlaczego polska socjologia nie przewidziala „Solidarności”, [w:] tegoż, Obrazy ż̇̀ycia socjologii w Polsce, Oficyna Naukowa, s. 243-265.

/// Surman J. 2014. Historyzowanie nauki lub jak nowe przychodzi na swiat. Rozmowa z. Hansem-Jörgiem Rheinbergerem, „Historyka. Studia Metodologiczne”, nr 44, s. 51-66.

/// Święcicki M. 1978. Revolutions in social sciences and the future studies movement, [w:] Future Research - Planning - Decision Making: Conference beld in Jabłonna, April 22-24 1977, red. W. Szulc, Ossolineum, s. 139-199.

/// Szacki J. 1980. Spotkania z utopia, Iskry.

/// Szczepański J. 1967. O metodżie præewidywania składu i struktur grup społecznych (rozważania wstęne), „Kultura i Społeczeństwo”, nr 3, s. 97-102.

/// Szczepański J. 1971a. Jaki będrie czlowiek proysztości?, [w:] Perspektywy XXI wieku. S₹̌kice futurologic₹ne, red. R. Doński, Książka i Wiedza, s. 16-26.

/// Szczepański J. 1971b. Myślenie o przysz̨ości, [w:] tegoż, Rozważania o Rz̨ecrypospolitej, PWN, s. 129-146.

/// Szczepański J. 1974. O konstruowaniu zarysu syntetycznego obrazu rozwoju spoteczeństwa polskiego do roku 2000, [w:] Spoteczny rozumój Polski w pracach progno- 
stycznych. Wydanie drugie, rozszerzone i uzupetnione, red. Komitet Badań i Prognoz „Polska 2000”, Książka i Wiedza, s. 13-32.

/// Szczepański J. 1989. Polska wobec wyzwań przysz̨ości, SSP „Universitas”.

/// Tarkowska E. 1999. Zespót Prognoz Spotecznych i jego kontynuacje. Spojrzenie z.perspek.tywy trzydziestu lat, [w:] Homo eligens. Spoleczeństwo świadomego wyboru. Ksiega jubileuszowa ku czici Andrzeja Sicińskiego, red. D. Gawin, IFiS PAN, s. 11-30.

/// Williams R.J. 2016. World Futures, „Critical Inquiry”, nr 3, s. 473-546.

/// Żółkiewski S. 1960. Integracja nauk społecznych i unspótcześnienie ich problematyki (propozycje redakcyjne), „Kultura i Społeczeństwo”, nr 1-2, s. 3-17.

/// Żółkiewski S. 1963. Præyczynek do teorii rewolucji kulturalnej, [w:] tegoż, Przepowiednie i wspomnienia, PWE, s. 215-227.

/// Żółkiewski S. 1967. Zagajenie: Zadania konferencji, „Kultura i Społeczeństwo", nr 4, s. 9-13.

\section{/// Abstrakt}

Artykuł przybliża socjologiczne myślenie o przyszłości w warunkach realnego socjalizmu, analizując cztery futurologiczne propozycje teoretyczne, powstałe w Polsce w latach 70. Umieszczone sa one w szerokim kontekście ówczesnych debat międzynarodowych, ograniczenia swobody (i wyobraźni) naukowej w monocentrycznym systemie decyzyjnym i oficjalnego dyskursu przywiązanego do marksistowskiej teorii postępu. Analiza tekstów futurologicznych Jana Szczepańskiego, Stefana Nowaka, Waldemara Rolbieckiego i Andrzeja Sicińskiego, powstałych w tak ograniczonych warunkach, ujawnia jednak ich oryginalne propozycje teoretyczne, pokazujące możliwe sposoby sensownego myślenia o przyszłości, redefiniujące pojmowanie historii, podejmujące problem indywidualnego i zbiorowego sprawstwa i granic jego przewidywalności. Tak odczytane, koncepcje te zyskują aktualność we współczesnych dyskusjach o antropocenie, w historycznych badaniach przyszłości czy w socjologii oczekiwań.

Słowa kluczowe:

futurologia naukowa, historia polskiej socjologii, socjalizm państwowy, Szczepański, Nowak, Rolbiecki, Siciński 


\section{/// Abstract}

This article draws attention to the role of sociological forecasting under state socialism. It analyses four conceptualizations of the future developed in the Polish People's Republic in the 1970s. These ideas are contextualised by transnational discourses on futurology, the constraints of science under the monocentric system of decision-making and ideological discourse officially confined to the Marxist theory of progress. These boundaries limited past prognoses. However, reflections on their function, prospective techniques and future orientation - which are exposed in futurological texts by Jan Szczepański, Stefan Nowak, Waldemar Rolbiecki and Andrzej Siciński - reveal a rethinking of modern concepts of history and temporality pointing far beyond the historical state socialist regime towards current redefinitions of temporal orders by the anthropocene and emerging research agendas such as historical future research, and the sociology of expectations.

Keywords:

scientific futurology, history of Polish sociology, state socialism, Szczepański, Nowak, Rolbiecki, Siciński

/// Lukas Becht - doktorant na Uniwersytecie Ludwika Maksymiliana w Monachium oraz Uniwersytecie Wiedeńskim (Cotutelle). Stypendysta polsko-niemieckiej szkoły doktoranckiej „Polska i Niemcy we współczesnej Europie" (LMU) oraz członek Research Cluster for the Study of East Central Europe and the History of Transformations (RECET) na Uniwersytecie Wiedeńskim. Przygotuje rozprawę doktorską nt. Studiów nad przysz̧ościa w transformacji z.późnego socjalizmu do gospodarki rynkowej w Polsce. Interesuje się epistemologią historyczną, historią myśli politycznej, rolą czasu i oczekiwań w praktyce społecznej i politycznej, ekologia.

Email: lukas.becht@univie.ac.at 
/// Piotr Filipkowski - socjolog, adiunkt w Instytucie Filozofii i Socjologii PAN, członek Research Cluster for the Study of East Central Europe and the History of Transformations (RECET) na Uniwersytecie Wiedeńskim, współtwórca i współpracownik Archiwum Historii Mówionej Ośrodka Karta i Domu Spotkań z Historią. Bada relacje między doświadczeniem a pamięcią i narracją autobiograficzną w różnych kontekstach empirycznych i teoretycznych. Interesuje się także filozofią i metodologia historycznie zorientowanych nauk społecznych.

Email: pfilipkowski@ifispan.waw.pl 